\title{
Political Structures and Political Mores: Varieties of Politics in Comparative Perspective
}

\author{
Marion Fourcade, ${ }^{a}$ Evan Schofer ${ }^{b}$
}

a) University of California, Berkeley; b) University of California, Irvine

Abstract: We offer an integrated study of political participation, bridging the gap between the literatures on civic engagement and social movements. Historically evolved institutions and culture generate different configurations of the political domain, shaping the meaning and forms of political activity in different societies. The structuration of the polity along the dimensions of "stateness" and "corporateness" accounts for cross-national differences in the way individuals make sense of and engage in the political sphere. Forms of political participation that are usually treated as distinct are actually interlinked and co-vary across national configurations. In societies where interests are represented in a formalized manner through corporatist arrangements, political participation revolves primarily around membership in pre-established groups and concerted negotiation, rather than extra-institutional types of action. By contrast, in "statist" societies the centralization and concentration of sovereignty in the state makes it the focal point of claim-making, driving social actors to engage in "public" activities and marginalizing private and, especially, market-based political forms. We test these and other hypotheses using cross-national data on political participation from the World Values Survey.

Keywords: political sociology; social movements; political participation; civil society; protest; comparative/historical sociology

Citation: Fourcade, Marion and Evan Schofer. 2016. "Political Structures and Political Mores: Varieties of Politics in Comparative Perspective" Sociological Science 3: 413-443.

Received: May 8, 2015

Accepted: December 23, 2015

Published: June 16, 2016

Editor(s): Jesper Sørensen, Sarah Soule

DOI: $10.15195 / \mathrm{v3} . \mathrm{a} 19$

Copyright: (C) 2016 The Author(s). This open-access article has been published under a Creative Commons Attribution License, which allows unrestricted use, distribution and reproduction, in any form, as long as the original author and source have been credited. (C)(i)
$\mathbf{T}^{\mathrm{T}}$ is a well-established fact that democratic countries differ in the extent and 1 manner in which their citizens "do" politics (Fourcade, Lande, and Schofer 2016). How they differ depends on what aspect is being examined. For instance, different indicators will give a more or less lively picture of American democracy. On the one hand, the US remains an associational nation: according to the World Values Surveys, roughly 60 percent of the people there have joined at least one voluntary group. On the other hand, voting rates in national parliamentary elections are low in comparative perspective (IDEA 2009). Americans also appear less prone to the more episodic forms of social mobilization that routinely stir many of the societies in Continental Europe and Latin America. More than one-third of Italian and French participants in the World Values Surveys from 1981 to 2008 had joined a demonstration, as opposed to only 17 percent of their American and 13 percent of their British counterparts; roughly 8 percent of the French and Italian interviewees, but 2 percent of the American and British ones, had ever taken part in a building occupation.

The scholarly literature on political participation tends to treat these different forms as relatively exclusive from each other. Academic disciplines and fields have cut up "politics" into a series of discrete objects (e.g., voting, civic engagement, social movements, lobbying, and more), each of which is presumed to obey its own institutional logics. Thus we have an extremely dynamic scholarship broadly 
focused on the Western social movement repertoire - strikes, demonstrations, boycotts, riots and other forms of social protest (McAdam, Tarrow and Tilly 2001; Tarrow 1988). Just as prominent is a more political science-centered literature framed around the broader notion of "civic engagement" - even "social capital" - whereby scholars refer essentially to voluntary associational activity (Putnam 2000; Skocpol 2003). These differences in terminology and disciplinary affiliations are not innocuous: the two concepts are understood to refer to different social processes and thereby imply widely different assumptions about the nature of politics. While civic engagement is often regarded as a quite "normal" and, indeed, valuable mechanism for getting things done, contentious social action is largely viewed as a more exceptional and disruptive political process.

This compartmentalization of the scholarly landscape is particularly difficult for comparativists to work with (see Kriesi et al. 1995; McAdam and Tarrow 2010; Schussman and Soule 2005; Verba, Schlozman and Brady 1995). It is not simply social capital, or social movements, that are structured differently across nations, but the entire domain of politics itself. The fact that these phenomena are seen as empirically discrete does not mean that they should be treated as analytically discrete. Some of the same factors that explain a country's position on one dimension of political participation (e.g. "civic engagement") might also account for the country's characteristics regarding other dimensions. For instance, it is not mere coincidence that what social movement scholars call "contentious politics" is not very frequent in Scandinavian countries, where elaborate institutional channels exist to support membership-based collective participation and negotiation. Conversely, people in different countries might engage in similar types of political activity for entirely different reasons. Thus, striking in the United States has neither the same character nor the same meaning as it does in Denmark, France, or the United Kingdom, for clear historical reasons (Carter et al. 2003; Hattam 1992; Katznelson 1985; Shorter and Tilly 1974).

The first purpose of this paper is to construct a comprehensive representation of politics across Western democratic nations, starting from the observation that different forms of political activity fit together in a broader ecology. Second, we argue that historical pathways into political modernity have generated different institutionalized models of political behavior - different political "mores," to use Tocqueville's words - which may account for the observable cross-national variability in political practices today. We demonstrate this proposition empirically using cross-national data from the World Values Survey. We show that (1) institutionalized forms of actorhood matter: highly corporate social structures funnel politics mainly through administered cooperation, producing political patterns that emphasize "membership" arrangements as opposed to more actively participatory ones. Less corporate societies, by contrast, have engendered a different type of politics. Conflict is made more visible and open forms of contestation, from demonstrations to political violence, are both more common and treated as more legitimate by the broader society (including by the majority of people who have never used these strategies themselves). We also show that (2) the general character of the state matters: in societies defined by high levels of what Jepperson (2002) calls "stateness," politics is mainly organized through explicitly political means and 
directed at the central government, whereas in non-statist (liberal) societies it is typically organized in a more "private" and decentralized fashion, via markets and private associations.

\section{Beyond Strategy: The Culture of Politics}

The ambition to compare whole "political systems," and the cultural approach to comparative politics, have their root in Almond and Verba's (1963) classic text, The Civic Culture. For Almond and Verba, and later Inglehart (1997), political culture was best studied by collecting data about subjective beliefs. But beliefs are hard to interpret, especially when scholars use them to explain differences across nations. How do you disentangle cross-national variations in "trust in political institutions" from cross-national variations in the cultural meaning of professing one's trust? Furthermore, beliefs may be only loosely connected to actual behavior (Vaisey 2009). Almond and Verba (1963:479) themselves pointed out the discrepancy: "there exists a gap between the actual political behavior of our respondents, on the one hand, and their perceptions of their capacities to act and their obligations to act, on the other."

Our approach is thus more behaviorist than the typical understanding of "political culture." Important intellectual shifts in sociology and history have sought to take culture "out of the realm of individual subjectivity" and frame it as "practices in interaction with discourse" (Swidler 2001:84; see Bonnell, Hunt and Biernacki 1999). Studying what people do (or, in this case, what they say they do) can provide as many, if not more, insights into the meaning of political participation than studying what they claim to believe in. As Swidler (1986) has argued, we must do away with the arbitrary distinction between value systems and behavior (and the causal relationship that presumably links them), and study instead how culture is constituted and expressed "in action."

Action, furthermore, is in part culturally scripted or "anchored" by institutions (Swidler 2001). There is thus reason to think that political behavior - how people "do" politics - varies in relation to the broader institutional system. Indeed, scholars have examined at length how institutions shape resources and resourcefulness, structure political opportunities and constraints, and provide vocabularies and meaning to social movement actors (Ganz 2008; Kitschelt 1986; McAdam, McCarthy and Zald 1996; Tarrow 1989, 1994a; Tilly 1986, 2003, 2008). Yet how institutions also structure the views and practices of non-participants may be just as important. For instance, even though strikers are a small minority of the population in practically every country, the popularity of strikes with the general public varies considerably. In this sense, what helps reproduce existing political patterns are the orientations from all segments of society, beyond those who participate, and beyond the legal instruments that formally regulate episodes of political contention. Political vocabularies and strategies are not only learned interactively, through opportunities to participate (Clemens and Minkoff 2004; Skocpol et al. 2000; Tilly 2008), but also through much more difficult-to-isolate forms of political osmosis: gleaned from news commentary, relatives' reactions to events, the involvement of distant friends, and so on. To understand cross-national differences in political repertoires and forms of mobilization, we must thus do away with what Walder (2009) calls 
"movement-centrism" and focus instead on the collective vocabularies, experiences, and practices of everyday politics (Sewell 1980).

The vast majority of collective action is carried out through the conventional means of street demonstrations, mass petitions, boycotts, and strikes, as well as by engaging in voting, lobbying, or legal challenges (McAdam and Tarrow 2009). Yet in spite of these commonalities, there are important cross-national differences in emphasis. What determines the different structure of the repertoire across nations, as well as the different nature of its constituent parts? First, consistent with social-movement theory (e.g. McAdam, McCarthy and Zald 1996; Tarrow 1988), institutional effectiveness matters. For instance, setting up an association might be perceived as a robust and reliable tool for establishing political or legal claims in a democratic society. But institutional effectiveness is not simply a matter of numerical organization and resources. It also depends on who is culturally recognized to speak or make claims. Thus, a petition in France or Germany may not need to rely on a mass movement to be effective: the endorsement of prominent elite members may be sufficient. Marx Ferree et al. (2002) offer a good illustration of this kind of dilemma. Describing abortion politics in Germany and the United States, the authors found their object to be closely dependent on each country's "discursive opportunity structure" (or the nature and organization of its public sphere).

This suggests that political strategies have a strong cultural dimension (Zhao 2010). Political practices are expressive in addition to being instrumental, and must be understood in relation to broader processes of group socialization and the articulation of social identities and emotions (Aminzade and McAdam 2001; Jasper 2011; Katznelson 1985; McAdam, Tarrow and Tilly 2001; Polletta and Jasper 2001; Sewell 1980). Hence, any understanding of the factors that underlie the differential structure of the political repertoire across nations must address the substantive meaning that the various forms of political action take for the individuals and groups who carry them out. To give an example, a street demonstration may look like a public ritual (such as a First of May parade), or it may look like a prelude to a riot.

Cross-national statistical analyses are usually limited in their ability to embed politics in culture, which has led some (e.g. Steinmetz 1999:24) to claim the superiority of detailed historical or ethnographic studies. There is no easy way out of this dilemma, but we, along with a few others (e.g., Bail 2008; Bonikowski 2010), also recognize that how we narrate and conceptualize statistical relationships might go a long way toward accounting for the meaning of politics on the ground. We suggest some theoretical avenues - however partial and imperfect - for acknowledging the cultural dimension of politics in spite of the conceptual and methodological limitations posed by quantitative analysis.

Our strategy consists in establishing a connection between variations in broad, historically evolved characteristics of polities and cross-national variations in current political practices. Institutions, we argue, must be seen as "essentially socio-cultural phenomena" (Nettl 1968). A large part of this cultural work is explicit. As Sewell (1999:55-56) notes, "much cultural practice is concentrated in and around powerful institutional nodes - including religions, communications, media, business corporations, and, most spectacularly, states. These institutions ... are all cultural actors; 
their agents make continuous use of their considerable resources in efforts to order meanings" (our emphasis). Think, for instance, about the elaborate institutional rites surrounding education (graduation), marriage (wedding), or government (inauguration). But much of the cultural work of institutions is more implicit, relying on the symbolic articulation of institutional practices whose histories remain hidden and which, therefore, come to acquire an almost natural character (see Bourdieu 2015). The relevance of the state to the organization and culture of politics may have to do more with its (taken-for-granted) structure and mode of operation, than with its strategic actions: "the boundary of the state (or the political system) never marks a real exterior. The line between state and society is not the perimeter of an intrinsic identity, which can be thought of as an intrinsic object or actor. It is a line drawn internally, within the network of institutional mechanisms through which a certain social and political order is maintained" (Mitchell 1991:90). Ultimately, the goal of a cultural approach to politics should be to help us conceptualize the changing form of this network across nations (what neo-institutional theorists such as Jepperson and Meyer (1991: 206) call "the organization of the polity") and how it "constitutes" individual actors and their practices.

In this paper, we explore the relationship between historically evolved forms of polity-organization and the contemporary, practical repertoires that people rely upon to engage in politics across countries. We start with a substantive analysis of the different institutional configurations that "man the boundary between state and society" (Almond and Coleman 1960:9, cited in Mitchell 1991:81) and between individual and group in a number of affluent democracies. We formulate a series of hypotheses regarding political structures and their relation to political mores in different societies. We then confront present-day observable behaviors with these cultural expectations, and only then do we conduct a limited exploration of subjective perceptions regarding these behaviors. In short, we develop a cultural argument through a mainly structural study.

\section{The Multifaceted Nature of the Political}

Table 1 reports descriptive statistics on a wide range of political practices in eighteen industrialized nations, based on aggregated data from 1980 to 2005. At first glance, we can detect a rough polar opposition between (approximately) Finland and Italy. Political governance in "corporatist," social-democratic Finland is routinely carried out through the operation of large, encompassing voluntary organizations (Rothstein 2002); spontaneous political actions are rare, and when they occur, they rely heavily on relatively non-confrontational forms of activism, such as petitions and boycotts. At the other end of the spectrum, Italy exhibits a much thinner civic organizational fabric - general associational membership levels are comparatively low, for example, and some of the most prominent forms of political mobilization (street demonstrations or building occupations) are located on the "contentious" side of the spectrum of political practices.

Table 2 presents the results of an exploratory factor analysis of these nationallevel measures of political participation (data and measures described below). 


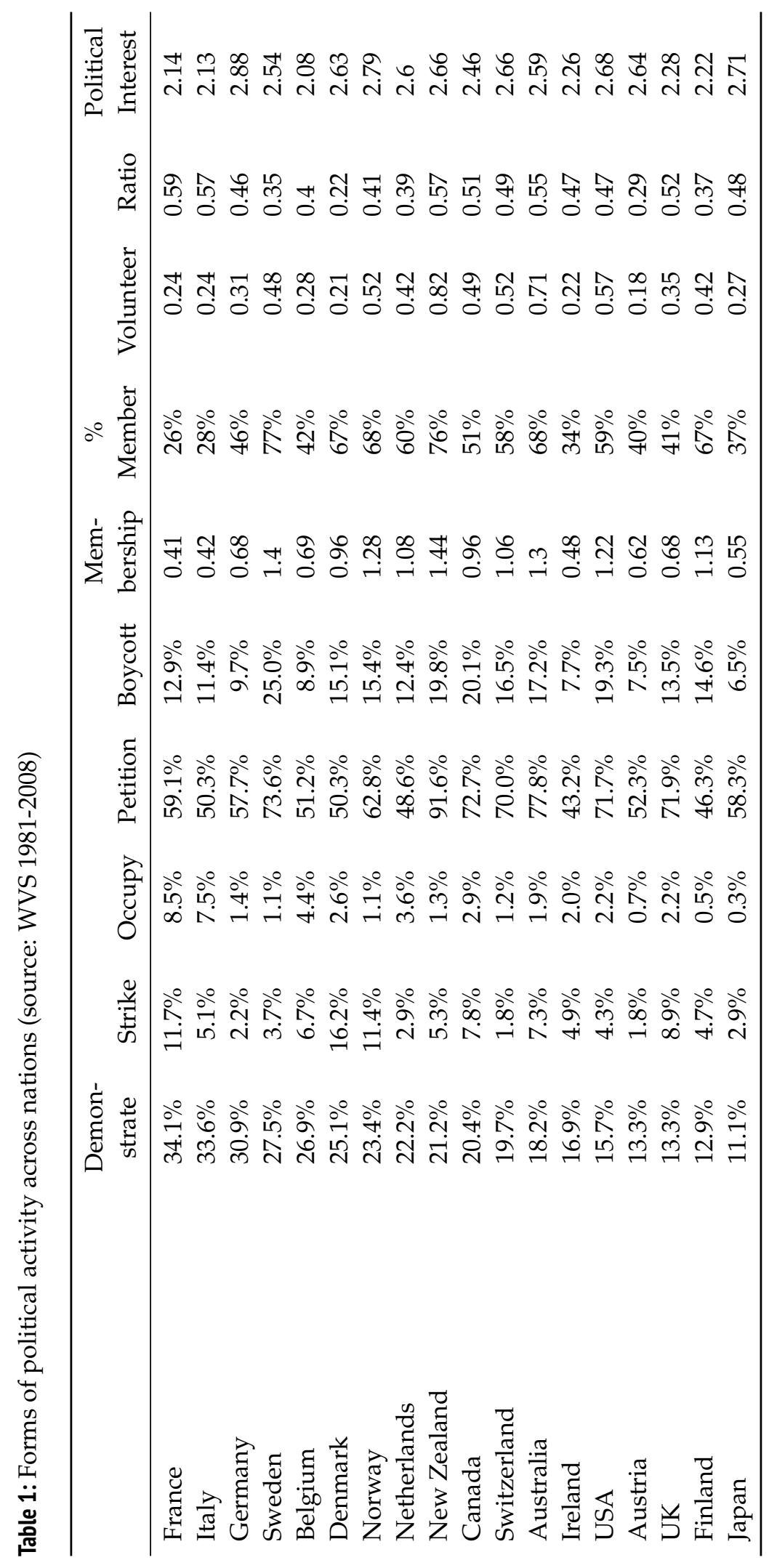


Table 2: Factor Loadings: Forms of Political Participation

\begin{tabular}{lrc}
\hline & Factor 1 & Factor 2 \\
\hline Demonstrate & -0.32 & 0.44 \\
Occupy & -0.64 & 0.62 \\
Strike & -0.08 & 0.15 \\
Petition & 0.72 & 0.53 \\
Boycott & 0.76 & 0.38 \\
Membership & 0.95 & 0.01 \\
Volunteer & 0.86 & 0.39 \\
Ratio & -0.07 & 0.84 \\
Political Interest & 0.58 & -0.3 \\
Trust & 0.71 & -0.38 \\
Voter Turnout & -0.13 & -0.12 \\
\hline
\end{tabular}

Figure 1 offers a graphic representation of Table 2's factor loadings, showing which political practices tend to cluster together in the full sample of nations. Figure 2 presents the national factor loadings, showing essentially which countries tend to resemble each other from the point of view of their political practices. The first factor tends to oppose individuals and countries that score high on voluntary associations' membership, as well as on volunteer work, boycotts and, to a lesser extent, petitions. Factor 2, on the other hand, singles out those countries and individuals who engage in demonstrations and building occupations. Figure 2 clearly shows, for example, that Anglo countries such as the United States, Canada, Australia, and New Zealand tend to score high on factor 1 (typified by high voluntary activity, petitions, and boycotts), while France and Italy score highest along the second dimension (typified by demonstrations, occupation of buildings, etc.). One could say much about the rich descriptive information in these plots, but the critical issue for our purpose is that the plots vividly highlight the structured and inter-related nature of political participation: forms of political activity are not isolated from each other, but rather exist in distinct configurations that vary systematically across societies.

This perspective calls for a revision of our political categories as well as the value judgments in which they are often embedded. From the point of view of traditional social capital indicators - e.g., trust, associational membership levels, organizational density (shown in Table 1 and captured by factor- 1 dimension in Figure 2) - civil society has often been deemed active in Sweden and comparatively more inert in Italy (especially Southern Italy — see Putnam 1994). Such a representation, however, is problematic. First, it relies on a questionable equivalence between high associational membership levels and a certain idea of democratic "activeness." Second, it fails to take into consideration alternative forms of political activity, such as protests.

What we know about levels of associational membership suggests that they cannot be attributed an a priori (positive) meaning outside the cultural/institutional context in which they take place (Portes and Landolt 1996). High membership levels in the voluntary sector may hide sheer parochialism in individual attitudes. American civic life, for instance, is localized and community-centered (Wuthnow 1998): a decentralized pattern of political governance prompts people to get involved in issues that are "close to home" (Eliasoph 1998). Hence, rather than contributing to 


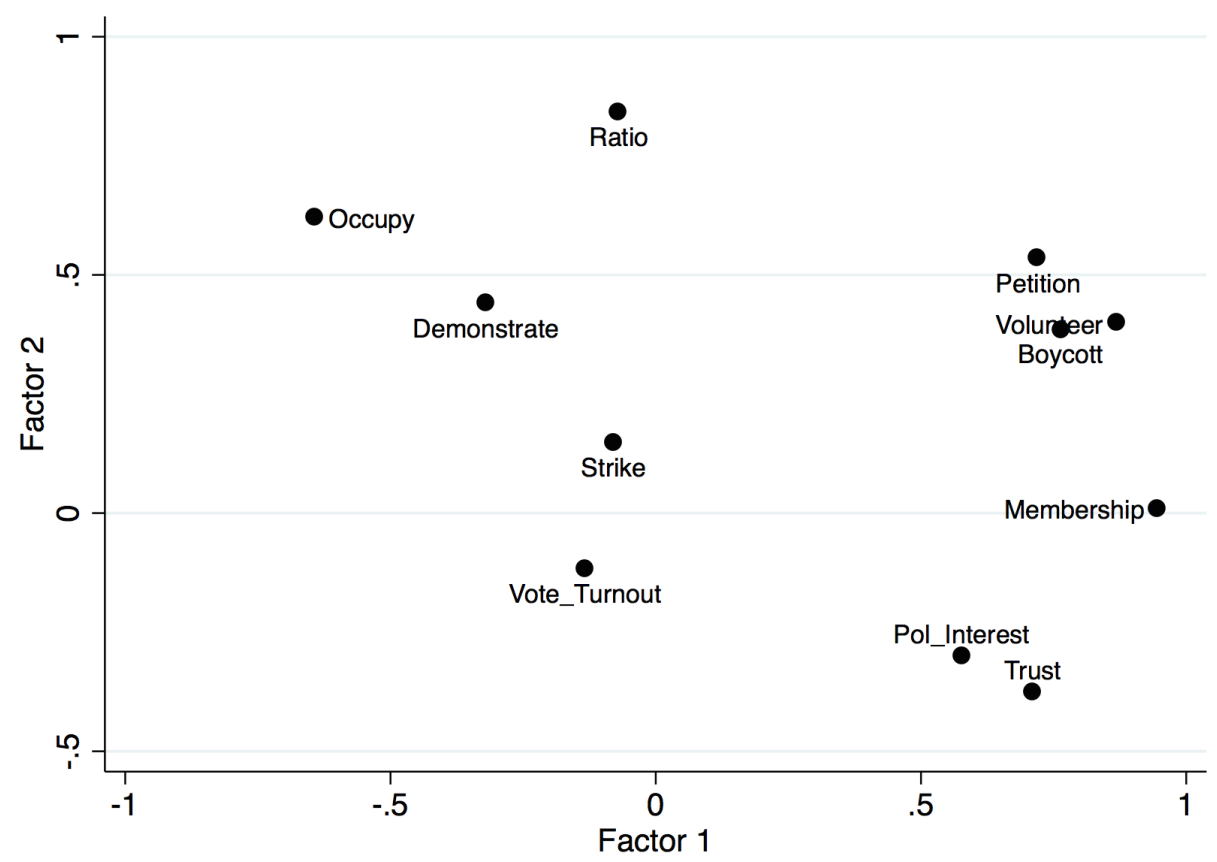

Figure 1: Factor loading plot: Exploratory factor analysis of aggregate national measures of political behavior and related measures.

the creation of a unified public sphere, high organizational density (social capital) may indicate or reinforce social divisions and political fragmentation (Kaufman 2002). Finally, as Berman (1997b:569) has argued, there is no simple relationship between civil society and political stability or democracy. Vibrant associational infrastructures have in some cases - most prominently Nazism (Berman 1997a) and Italian fascism (Riley 2010) - helped bring them down.

Conversely, while political protest is seen as a potentially disruptive and dangerous force, the reverse might be true in some societies. Political socialization takes place through very different mechanisms in different countries: it may naturally involve joining a local association in the United States or a national interest group in Sweden - but participating in national street demonstrations in France (Favre 1990). As Albert Hirschman (1994:206) has argued, under certain conditions conflicts can be an "essential factor of socialization" and "an eminently efficient producer of integration and cohesion" (see also Ganz 2008; Jasper 2011).

Finally, levels of associational membership tell us very little about the amount of effective political activity within a particular society. Intuitively, we would expect national levels of membership in voluntary associations and levels of active participation in voluntary associations to co-evolve. And, to a certain extent, they do. Countries with high levels of membership in voluntary associations also have high rates of participation, and vice versa. Yet, if we look at relative rates of active participation, as measured by the ratio of the number of active members over the total number of members, we find that countries such as Italy and France tend to have proportionately higher ratios of active participation. Conversely, some of the nations that exhibit 


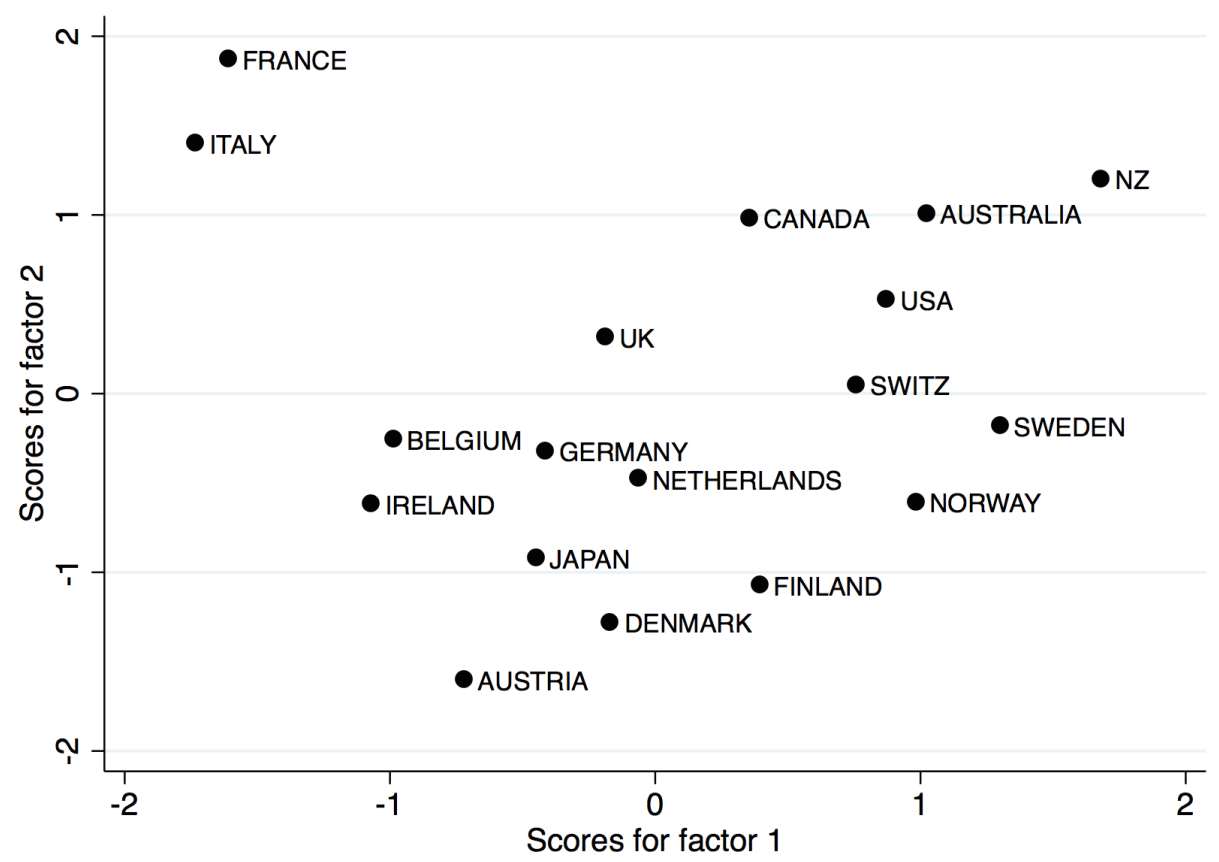

Figure 2: Country factor score plot: Exploratory factor analysis of aggregate national measures of political behavior and related measures (e.g. trust, political interest).

the highest levels of membership in voluntary associations also have some of the lowest ratios of active participation (e.g., Sweden and Norway - see Wollebaek and Selle 2003:83). Even in liberal countries, scholars have noticed the sharp rise of "paper membership organizations" (Skocpol 2003) during the twentieth century.

How should we make sense of the varying configurations of associational membership and active participation? To explain the Scandinavian puzzle, some scholars have argued that neo-corporatism and welfare-state institutions generally have a "hollowing out" effect on political participation by creating a professionalized elite of association leaders and removing the need for individuals to get "actively" involved. ${ }^{1}$ The low "volunteer work/membership" ratio in Sweden can be connected analytically to Sweden's low scores on strikes and building occupations. Although the explanation is seductive, we believe that something more fundamental is at work than the institutional shaping of individual incentives for political mobilization. What accounts for Sweden's surprising mix of high membership and moderate activity, we argue, is a culturally distinctive understanding of the very nature of politics. Corporatism, in this respect, is not simply a system of interest mediation that channels collective action in certain directions; it is, first and foremost, a set of institutionalized political practices whereby people "act" as members of preexisting social groups rather than as atomized individuals. 


\section{Polity Characteristics and Cross-National Variations in Po- litical Forms}

We thus seek to understand empirical patterns of political mobilization across countries in relation to the institutionalized organization of the polity. Our approach is similar to Kriesi's (1996) emphasis on the "general political context", notably the strength of the state and its responsiveness to challenges. For instance, Kriesi et al. (1995) demonstrate that the general character of the political opportunity structure, such as fragmented (Switzerland) or very centralized (France), shapes the nature and intensity of social movements. Here, however, we want to emphasize that these "stable aspects of the political opportunity structure" (Kriesi et al. 1995: xxv) have cultural effects, too: they constitute the meaning and social legitimacy of various courses of action and various types of organizational actors (Berger and Luckman 1966; Friedland and Alford 1991; Thomas et al. 1987). We find an especially clear formulation of this point in Jepperson $(1993,2002)$, who conceptualizes the political structure as having two critical cultural dimensions: the organization of society (degree of corporateness) and the location of public authority (degree of stateness).

\section{Corporateness}

Scholars have proposed numerous definitions of corporatism, emphasizing a system of interest representation (Schmitter 1974) or the system of incorporation of the working class into the capitalist state (Lijphart 1999; Offe 1983; Panitch 1980). ${ }^{2}$ What few of these analyses recognize, however, is that corporatism, as a mode of political governance, is fundamentally embedded in specific historical-cultural trajectories, particularly what Jepperson (2002) calls the "corporateness" of the social structure. "Corporateness" refers to the extent to which the political, legal, and economic make-up of a society has been historically organized around "communal" orders that grant a higher moral purpose to organized human collectives - such as families (Beckert 2007), religious brotherhoods, local communes, and occupations. Fundamentally, "the distinction between more corporate and more associational organizations corresponds to a fundamental historical differentiation between a society of orders (e.g., estates) and a society of individuals organized into classes or other associations" (Jepperson 2002:65).

Historically, European societies were "corporate" in many different ways. For the sake of simplicity, we distinguish between two main forms. On the one hand, the upper segment of society was organized into exclusive and monopolistic "orders" - typically the aristocracy and the clergy — whose feudal or quasi-feudal privileges were protected by law and custom. On the other hand, distinctions were also established between groups of people on the basis of location, trade, or social function. These corporate rights were often embedded in forms of collective jurisdictional control granted and guaranteed by the state. In some ways, they have survived through the differentiated organization of social benefits and protections for various collective groups. Thus, modern students of corporatism, most famously Esping-Andersen (1990), looked at the existence and number of 
occupationally distinct public-pension schemes to measure a society's degree of "corporatism."

Neo-corporatism is rooted historically in long-standing cultural understandings and social practices, usually bolstered by state authorization and patronage. In its modern form, neo-corporatism provides public standing and official representation to social groups mainly on the basis of their social function in the capitalist economic system. According to German sociologist Claus Offe, corporatist political structures shape civil society through the implementation of policies that assign public status and public roles to human collectives. Concretely, corporatist states will typically (1) supply important material resources to interest groups, (2) legally define their range and substantive area of representation, (3) regulate relations between rankand-file and executive members within these organizations, and (4) invite corporate groups to assume a role in legislation, the judicial system, policy planning, and policy implementation (Offe 1983:137). Some countries (notably Sweden, Denmark, and Germany) are distinctive in having established early partnerships between voluntary organizations and state welfare institutions (Gaskin and Smith 1997).

In some societies, corporatist political governance was never institutionalized successfully, even if attempts were made, as in post-war Britain and France. Britain represents a classic example of a non-corporate route into political modernity. Political revolution, reformation, and early industrialization produced an understanding of political life in which individuals were the true, legitimate locus of interest and citizenship. In British social thought, civil society is represented as the expression of a natural order forged by "free" individuals engaged in their personal political, religious, or economic pursuits. Adam Smith's metaphor of the invisible hand perhaps captures best this idea of social harmonization as a natural outcome of individuals following their own self-interests. With some variations, the British transmitted this "individualistic" culture to their settler colonies (United States, Canada, Australia, New Zealand), which were devoid of corporatist European medieval legacies and thus mostly non-corporate "de novo" (Jepperson 2001).

But there are other historically evolved forms of individualist political culture. French individualism constituted itself more as an "anti-corporate" force. Corporate groups in France, subjected to attacks by the monarchy and revolutionary governments alike, have had a tortured history. During the Second Revolution, the French poet and politician Lamartine gave an eloquent exposé of his horror of intermediate bodies: "Corporations... are the most achieved form oppression may take to crush both individual and general interests; ... Corporations or (what looks quite like them) organized collective interests recognized in law are one and the same thing; they are the immediate, unavoidable, everlasting enslavement of all other forms of interest" (our emphasis). ${ }^{3}$ As in liberal polities, then, the French looked at corporate bodies as expressions of privilege and therefore as threats to individual liberty. However, as the above quote suggests, they also perceived them as a corruption of the general interest of the people. French liberalism, in contrast to its Anglo-Saxon variant, regards the general interest as superior and external to individuals, and indeed often in conflict with them, rather than as the outcome of a spontaneous harmonization of their particular interests. The general interest is altogether philosophically separate, first and foremost represented by the state, the 
only particular "interest" deemed legitimate to carry out the "public" good. There is no natural coordination of public and private as in utilitarian liberalism. Hence, France is both anti-corporate and statist (we discuss the variable stateness in the next section).

The Southern European and Latin American countries share with France a "statist" ambivalence toward corporate groups. Still, the political regimes in these nations have also claimed their attachment to a corporate organization of society for long periods of time over the course of the twentieth century. The word corporatism, for one thing, is derived from the Italian corporatismo, which refers to the attempts made by the fascist regime of Mussolini to incorporate people into the state through their group affiliations. However, as Dyson has argued, fascist corporatism always "amounted to little more than a façade" (1980:59). ${ }^{4}$ A still more conservative understanding of corporatism, rooted in the Catholic model of paternalistic social order, was institutionalized (particularly in the labor code) under the dictatorships of Franco (1936-1975) in Spain and Salazar (1928-1968) in Portugal, as well as the authoritarian regimes in Brazil, Argentina, Mexico, and Chile. This form of social organization, however, remained fundamentally centralized and state-directed, effectively barring large sections of the population (e.g. peasants, government workers) from participation (Wiarda 1982). In this respect, "bureaucratic-authoritarian" corporatism should be viewed foremost as a mechanism for the exclusion, rather than the incorporation, of the popular sector (O'Donnell 1977). In its Latin American forms, it remained a highly unequal, partial, and fragmented mode of societal organization, where state and society were connected mainly through vertical clientelistic relations. Our interpretation, then, is that Iberian and Latin American corporatism is fundamentally a form of statism (what O'Donnell (1977) calls "statizing corporatism") — that is, social control by the state overrides political incorporation. Thus, we should not be surprised when these countries rank quite low on major corporatism indices (e.g., Lijphart 1999).

As suggested by authoritarian regimes' (ultimately failed) attempts to govern society through organized groups, the corporate mode of social organization is fundamentally a mechanism for the production of political order. Consequently, it should have powerful effects on the scope and shape of political mobilization, which we explore by formulating three hypotheses. First, by attributing public status to organized collectives as opposed to individuals, by providing them with material support, and by publicly legitimating their role through incorporation into the policy process, corporateness should tend generally to encourage formal organizing (Hypothesis A1). We should expect, for instance, corporate social systems to exhibit high levels of membership in collective organizations because being a member of an official, collective organization is socially constructed as a normal and highly legitimate mode of political incorporation. Membership in organized groups will be understood more as an attribute of each individual's "social self" than as the expression of his or her personal choice (Jepperson 1992). For example, being a worker in a particular industry will imply carrying a union card (in some cases, contribution and membership will be compulsory). It thus compels one to selfdefine primarily as the member of a group or a social category whose legitimate claims are represented in a collective, organized fashion, thereby forcing strategic 
interdependence and consensus with other individuals (Streeck and Schmitter 1985).

The second point, then, is that by associating certain interest groups to the formulation of public policy, neo-corporatism restricts the "scope of the participants in conflict and the strategies and tactics that are permitted in the pursuit of conflicting interests" (Offe 1983:141). The collective and institutional incorporation of individual claims and grievances in corporatist social systems is thus geared towards the neutralization of social conflict, thereby shaping the meaning and possibilities for collective action. If membership in collective organizations is a routine, taken-forgranted element of political incorporation, then it is unlikely to translate into high levels of activism. We thus expect individuals in corporate polities to do less volunteer work relative to their membership levels (Hypothesis A2). Finally, because of their cultural valuation and institutionalized handling of conflict negotiation, we should also expect individuals in corporate societies to engage less in all forms of protest action (Hypothesis A3) - be they street demonstrations, building occupations, strikes (especially), petitions, or boycotts - compared to those in non-corporate societies. Corporate societies frown upon demands formulated through these means, particularly if they appear to be rooted in self-interest. As the above section suggests, what we know about patterns of political activity in countries like Sweden and Germany (Nollert 1995; Wollebaek and Selle 2003) seems to confirm this point.

\section{Stateness}

Broadly speaking, "stateness" refers to the extent to which societies attribute separate and superior status to the institution of the state and locate political sovereignty in that institution. If the historical differentiation of state institutions through bureaucratic rationalization is a general phenomenon, the way in which this "rise of the rational state" has unfolded (that is, its timing, pace, nature, and extent) differs quite substantially across countries. Silberman's (1993) four-way comparison of nineteenth-century administrative expansion, for instance, reveals a polar opposition between the monopolization of expertise and information by state structures in France and Japan, on the one hand, and the continued reliance on voluntaristic social bodies in the United States and Great Britain on the other (Hall 2002; Skocpol 1995). Consequently, in the first two cases, the central bureaucracy became the source of organizational standards for the rest of society (Silberman 1993:417). Furthermore, the state administration is so well institutionalized in these societies that it also dominates the political and economic systems. ${ }^{5}$

The very concept of state is far from homogeneous across European countries (Dyson 1980). The most remarkable, even aberrant, case is England, where both the concept and practice of the state remained underdeveloped for a very long time. When the rest of Europe was producing "theories" of the state and developing complex public bureaucracies, England was still faithful to its medieval traditions and continued to present a sharp "disinclination to explore ideas about the distinctive character of public authority" (Dyson 1980:43). After the Magna Carta in 1215, political sovereignty in England was subject to complex patterns of cooperation and conflict between the crown and the aristocracy, which the rev- 
olution of 1688 definitively settled in favor of the latter. Ambiguities about the origin of executive power persisted with the adoption of the constitutional formula of Crown-in-Parliament; as a result, the concept of state in England "remained a theoretically underdeveloped and lifeless abstraction" (Dyson 1980:43).

Ambivalence toward the state is also evident in America. Consistent with the liberal tradition from which it originated, the United States exhibits a similar pattern of relative "statelessness" in its conception of political sovereignty - that is, a considerable defiance against the political center remains lively in American political culture. Against "government," American social thought centers on a democratic civil society from which sovereignty is ultimately thought to derive (Somers 1995). The result is the lack of a unitary conception of the state, most evident in the meticulous separation of powers and in the long American history of federalism. This does not mean, of course, that the American state institutions are "weak," only that their exercise of power is organized differently — relying more on "infrastructural" penetration than "despotic" rule, to use Michael Mann's conceptualization (1986; see also Novak 2008:763).

Much of the rest of Europe offers a striking contrast with Britain and the United States. There, the heritage of Roman law forged distinctive ideas about the separation between the public and private domains. ${ }^{6}$ France, like Germany and Italy, institutionalized "administrative science" as a separate subject; likewise, a distinct body of law applies to the state only (Dyson 1980:181-182). The bureaucracy developed as a separate status group endowed with numerous privileges, many of which continue into the present day. For instance, welfare-state research has shown that in "conservative welfare states" such as France, Germany, Austria, Italy, or Belgium, the civil service has access to relatively generous benefits and pensions (Esping-Andersen 1999:82). These patterns are in contrast to the Scandinavian countries (and the Netherlands), where such benefits are more universally and equally distributed among the population. As Dyson (1980:69) has argued, while these nations do recognize the distinctiveness of the civil service, they - not unlike the United Kingdom or the United States - tend to emphasize its co-equality rather than its superiority. Consequently, their legal system, which is a mix of continental civil law and customary Scandinavian rules, also sets them apart from the continental European tradition. As in liberal countries, the routine (but much more formalized and centralized) involvement of collective organizations with central authorities further blurs this boundary between the state and society (Boli 1991). There is thus good reason to view Scandinavian countries as relatively non-statist, in spite of the large size of their public sector and some of the highest tax rates in the world (Jepperson 1993).

We formulate four hypotheses regarding the effect of stateness on political mobilization. Our first hypothesis is that stateness tends to discourage membership in voluntary associations (Hypothesis B1) (Schofer and Fourcade-Gourinchas 2001). This occurs for several reasons. First, the centralization of political activity in the state tends to delegitimize organizational capacities coming from below. Institutionally and culturally, private groups have little standing in the polity, and this is reflected in the policies and legal rules that apply to them. In addition, the voluntary sector in statist countries typically does not enjoy governmental approval through political 
support and a favorable tax status, as in the United States or the United Kingdom, or generous public financing, as in Scandinavia (Anheier 1991).

Given the small number of voluntary associations, we do not expect stateness to have a positive effect on volunteer work. We do, however, suspect that once people are members of associations, they will be more likely to do volunteer work in statist than in non-statist countries. The reason is that (1) achieving goals by associational means may take more effort than in countries where the third sector receives official encouragement and institutional support, and (2) the associational sector is therefore likely to select individuals who are particularly active and motivated. Hence our second hypothesis: stateness will increase the likelihood that members of voluntary associations will be actively involved in them (Hypothesis B2).

The centralization of sovereignty and legitimacy in state bureaucracies that are both elitist and insular makes statist regimes quite unresponsive to external constituencies and generally resistant to change (Crozier 1973). In fact, change typically occurs through the application of massive collective pressure, such as mass demonstrations or a "general strike." A highly autonomous state will tend to "politicize" society by being the unique interlocutor, and thus the focal point, of both contention and claim-making. With political sovereignty vested outside of civil society, and few formal channels of incorporation available, the state will be mainly responsive to highly visible forms of political action, particularly those mobilizing in the street, such as demonstrations and building occupations (which are often directed at central administrative buildings). In his analysis of the French Old Regime, Tocqueville (1856) had already remarked that the fundamental contradiction of the system resided between the extreme dirigisme, minimal regulations and controls at the top, and the chronic disobedience manifested by the bottom. The centralized and closed nature of political sovereignty, he argued, tends both to fragment civil society and to push it to act at the margins - a point also acknowledged by Tilly (1986).

Consequently, we expect that in statist countries the national political repertoire will shift toward forms of mobilization directed toward the political center, such as street demonstrations and building occupations (Hypothesis B3). Conversely, we expect more "private" forms of political activity - particularly those organized in a more decentralized fashion and/or using primarily market pressure, such as boycotts - to be weaker in statist polities (Hypothesis B4). The question of strikes is particularly thorny and brings to light the complexity of the issues at hand regarding the cultural meaning of various political strategies. In many instances, strikes are an eminently decentralized, market-oriented form of action, directed at putting economic pressure on businesses for the purpose of settling controversial issues between management and labor. Indeed, scholars of strikes have repeatedly shown the local, often plantspecific, character of the practice in the most market-oriented economies, such as the United Kingdom and the United States. In other contexts, however, strikes may have a much broader political purpose, involving an entire industrial sector or even the whole of society in a massive, albeit usually short-lived, public movement. The most well-known example of this phenomenon is the Southern European (i.e., Spanish, Italian and French) tradition of the "general strike" (Shorter and Tilly 1974). Obviously, the meaning of such actions is more explicitly political, especially 
since the public sector is often at the vanguard of such movements. Given such cross-national variation in purpose and form, differences in legal and corporate responses (Voss 1996), and the poor wording of the question regarding strikes in the World Values Survey, we refrain from formulating a hypothesis regarding this particular form of action.

\section{Data and Measures}

We use data on individual civic participation from the integrated World Values Survey/European Value Study (henceforth WVS) dataset, which compiles surveys from a large number of countries over the period 1981 to 2008 (EVS 2011; WVS 2009). Our study focuses on eighteen industrialized democracies for which high-quality measures of stateness and corporateness are available. We pool available waves of data, yielding a sample of nearly 80,000 individuals. We also present results for a sample of 38 countries, based on a simpler dichotomous measure of stateness and corporateness, with additional controls for trust and post-materialism (see online supplement B). We describe our variables and measures below.

\section{Forms of civic participation}

Membership in voluntary associations. We measure association membership in a manner consistent with prior studies (see Curtis, Baer, and Grabb 2001; Curtis, Grabb, and Baer 1992). The WVS asks whether individuals belong to voluntary associations of various types. We focus on seven types of associations: welfare, education, unions, political associations, human rights, professional groups, and youth organizations. We summed these dichotomous measures to yield a count.

Volunteering. The WVS asks whether individuals do "unpaid work" for each type of association. Again, we summed the total number of organizational types to create an index.

Active membership ratio: Active participation to passive membership. We computed the ratio of the national average of the "volunteering" variable to the national average of the "membership" variable. Higher values thus indicate more active volunteering compared to passive membership. To create an individual-level measure, we divided our volunteering variable by our membership variable for each individual (adding 1 to the numerator and denominator to avoid division by zero; alternate approaches to constructing the index produced similar results).

Participation in demonstrations, Participation in strikes, Participation in boycotts, Occupying buildings, and Signing petitions. We measured each type of participation separately, with a dichotomous variable coded 1 for individuals who have "actually done" this type of activity.

Political Interest. We examine self-reported political interest, measured on a 4point ordinal scale ranging from "Not at all interested in politics" to "Very interested in politics." 
National-level variables

Stateness. We measure national history of stateness using an index of three measures: (1) Esping-Andersen's (1990) "etatism" variable, described in The Three Worlds of Welfare Capitalism. The measure captures the presence of an elite civil service, as reflected in government spending on public employee pensions; (2) Jepperson's $(1993 ; 2002)$ dichotomous measure of stateness, which was extended by Schofer and Fourcade-Gourinchas (2001); and (3) La Porta et. al's (1998) dichotomous measure of French/German legal traditions, which reflects institutionalization of statist traditions in the legal system. We z-scored the three measures and combined them into an index.

Corporateness. We capture a national history of corporateness with two measures: (1) Lijphart's (1999) corporatism index, which contrasts corporate vs. pluralistic interest-group representation, and (2) Jepperson's dichotomous corporatism measure (Jepperson 1993, 2002; Schofer and Fourcade-Gourinchas 2001). As with the stateness variable, we $\mathrm{z}$-scored these measures and summed them to create an index.

Democracy. The open political opportunity structure and political culture of highly democratic societies may encourage political activity. We use the polity democracy index from the Polity IV dataset (Marshall and Jaggers 2007).

Economic Development. Participation may be higher in affluent highly-industrialized countries. We measure development by the natural log of gross domestic product (GDP) per capita in constant US dollars (World Bank 2010).

\section{Individual-level variables}

We also address a wide range of individual-level factors, consistent with the prior literature (e.g., Brady, Verba and Schlozman 1995; Curtis, Baer, and Grabb 2001).

Age and Age-squared. Respondent's age, measured in years. We include agesquared to address non-linearity (Curtis, Grabb, and Baer 1992).

Gender. Coded dichotomously (male $=1$ ).

Education. Coded on an ordinal scale, ranging from "some elementary education" to "completion of university degree."

Marital Status. A dichotomous measure coded as one for respondents who are married or "living together as married."

Religiosity. Coded on a 4-point ordinal scale ( $4=$ more religious).

Employment Status. Coded dichotomously (employed $=1$ ).

We explored a range of additional control variables, such as left-right ideology, urban vs. rural residence, respondent's income, religious affiliation, and many others. At the national level, we examined educational enrollments, alternate measures of democratization (e.g., duration of democracy, Freedom House democracy score), and interaction effects. Our main findings were robust to the inclusion of these additional variables. 


\section{Methods}

We estimate multilevel models to analyze individual political participation, as individuals in our dataset are nested within countries (Bryk and Raudenbush 1992). We specify a simple random-intercept model:

$$
\begin{aligned}
& \text { Participation }=\beta_{0}+\beta_{1}(\text { Age })+\beta_{2}\left(A g e^{2}\right)+\beta_{3}(\text { Male })+\beta_{4}(\text { Education }) \\
& +\beta_{5}(\text { Married })+\beta_{6}(\text { Religiosity })+\beta_{7}(\text { Employed })+\epsilon \\
& \left.\left.\beta_{0}=\gamma_{00}+\gamma_{01} \text { (Stateness }\right)+\gamma_{02} \text { (Corporateness }\right)+\gamma_{03}(G D P) \\
& +\gamma_{04}(\text { Democracy })+v_{0}
\end{aligned}
$$

We use multilevel logistic models for dichotomous participation outcomes and multilevel negative binomial models for membership and volunteering. We use multilevel linear models for the active-membership index and political interest.

\section{Results}

We provide descriptive statistics in the online supplement $\mathrm{A}$. Table 3 presents the results of multilevel models predicting political and civic behaviors and political interest. We present two-tailed significance tests throughout to simplify presentation, rather than switching between one-tailed and two-tailed tests. Note, however, that significance levels are conservative for our key claims regarding stateness and corporateness, as one-tailed tests are justifiable.

Consistent with prior research, membership in voluntary associations tends to be significantly higher in more corporatist states and significantly lower in more statist countries (Schofer and Fourcade-Gourinchas 2001). These results support Hypotheses A1 and B1, respectively. A one-point increase in corporateness has an extremely large positive effect, corresponding to a 57 percent greater count on our membership index (exp[.449]=1.57; $(1.57-1)^{*} 100=57$ percent). A one standarddeviation increase in corporateness corresponds to a 141 percent higher membership count $\left(\left(1.57^{\wedge} 1.95-1\right)^{*} 100=141\right.$ percent $)$. Likewise, the stateness coefficient is negative and highly significant, with each point-increase in statism reflecting a 24 percent lower count on the membership index $\left(\exp [-.276]=.759 ;(.759-1)^{*} 100=-24\right.$ percent). As statism increases a full standard deviation, membership is halved ((.759^2.52 1) $* 100=-50$ percent).

Table 3 also presents results regarding volunteering. Again, stateness has a negative and significant effect, consistent with the claim that this type of polity tends to make any type of voluntary sector involvement more difficult. The effect of corporatism on volunteering is an order of magnitude smaller than the effect on membership and is only marginally significant. Thus, while corporateness drives membership up, it has very little effect on volunteer work.

We also examine the relative tendency to do volunteer work versus passive membership using our "active ratio." Consistent with our prediction (Hypothesis B2), stateness has a positive effect on the ratio, indicating that individuals in such 
countries are more prone to doing unpaid work as opposed to merely "joining" associations. In other words, while volunteer work tends to be generally low in statist countries, it is relatively high in proportion to membership. Supporting Hypothesis A2, corporateness has the opposite effect: individuals are more likely to be members, but comparatively unlikely to do unpaid work.

The notion that stateness generates distinctive forms of civic participation is apparent in the models concerning street demonstrations and building occupations. Results in Table 3 show positive and significant effects of stateness on both of these outcomes, supporting our prediction (Hypothesis B3) that these more "public" forms of political behavior are indeed more common in statist countries. A one standard-deviation increase in statism corresponds to a 27 percent higher odds of having demonstrated $\left(\left(1.10^{\wedge} 2.52-1\right)^{*} 100=27\right.$ percent). Corporateness, by contrast, has a negative effect on both demonstrations and occupation of buildings (the former is only marginally significant in a 2-tailed test). The effect of GDP is positive across both outcomes. Democracy has a marginally significant positive effect on participation in demonstrations and no effect on participation in building occupations.

Participation in strikes is less common in more corporatist societies. This confirms the notion that strikes are less legitimate (and possibly less necessary) where corporatist arrangements exist to incorporate workers' claims (see also Western 1997 on this point). Stateness has a negative effect on strikes, which is very close to statistical significance (the effect becomes significant in larger-sample analyses in online supplement B). Participation in strikes becomes more common as a country's wealth increases and slightly less common as the level of democracy increases.

Boycotts are a characteristically non-statist, non-corporate form of political activity. Accordingly, both stateness and corporateness are negatively associated with signing a petition, all else equal. As suggested above, we must understand boycotts as decentralized, market-oriented strategies that simply do not resonate well with the political repertoire in statist and corporate countries.

Signing petitions, like other non-membership forms of political activity, is significantly less frequent as corporateness increases. Stateness has an insignificant negative effect that is small, which seems to suggest that petitions are not only one of the best-accepted elements of the political repertoire everywhere (more than 60 percent of all respondents have signed one), but that as a political strategy, they are less culturally distinctive than the others.

To explore the generalizability and robustness of these findings, we analyzed a larger sample of 38 WVS countries using alternative measures of statism and corporateness (see online supplement B). Key findings are supported, and several coefficients are more highly significant with the larger sample.

In summary, in statist countries, the more "private" forms of political participation, ranging from voluntary associations to the more market-oriented elements of the modern political repertoire (e.g., boycotts and strikes), receive comparatively less emphasis than the more "public" ones, such as street demonstrations. Corporateness, on the other hand, orients people toward membership in large groups based on social categories, but relatively little active participation follows 


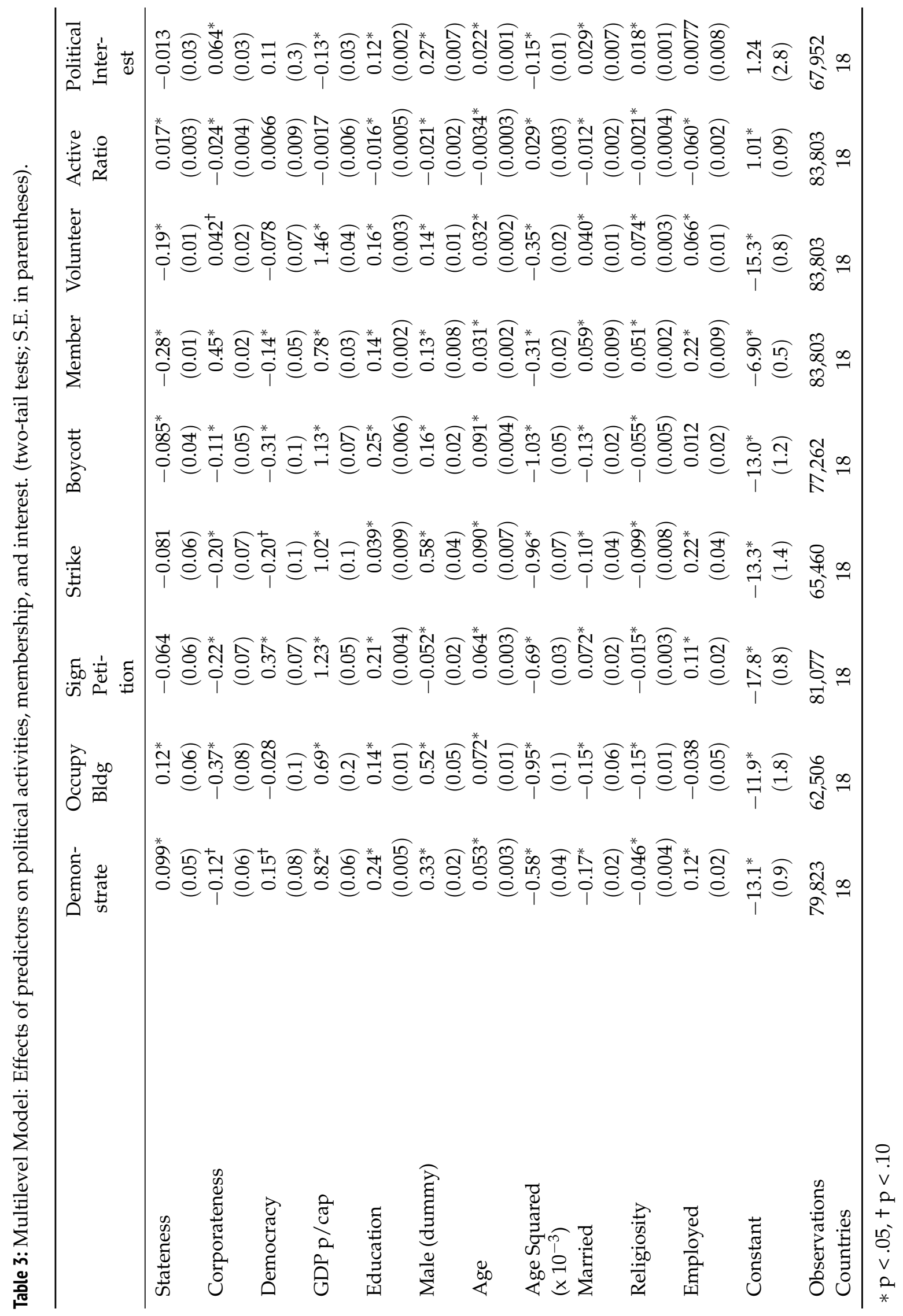


from this. This contrasts with the relative activeness in voluntary associations found in statist societies. Compared to corporatist societies, these societies provide less encouragement and institutional support for civil-society associations, which could result in more highly motivated (if fewer) association members and more active participation by them in order to achieve their goals.

Finally, the stateness and corporateness dimensions have additive effects. Societies that are both statist and corporate tend to be in the middle of the road in terms of contentious politics - the respective effects cancel out. In statist, non-corporate societies (e.g., France, Italy), the effects combine to produce higher levels of contentious political forms, while the converse (non-statist, corporate polities, such as Sweden) are found on the "membership" end of our imaginary spectrum.

It is also possible that these factors could operate interactively, rather than simply additively. This makes sense theoretically: at the level of cultural meaning, the two dimensions surely combine to create a distinctive configuration. Yet, analyses yield few results of interest (tables available from authors upon request). We do observe small negative interactions between stateness and corporateness for all measures of contentious politics. In general, the conjuncture of stateness and corporateness has a further dampening effect on contentious participation than corporateness alone. Or, equivalently, the effect of statism is more potent in non-corporate contexts. We observe a similar effect on association membership. The interaction between stateness and corporateness, however, is positive in the case of volunteering and political interest (the latter is only marginally significant). Jointly, then, statism and corporateness yield "interested" and active volunteers who are unlikely to engage in contentious political actions. Beyond this, interactions were non-significant. For the most part, statism and corporateness operate additively.

A final issue concerns the temporal variability. Our main analyses combine all five waves of the WVS - both to simplify presentation of results and because our theoretical expectation is that stateness and corporateness are durable features of societies that operate consistently over time. Nevertheless, we can straightforwardly estimate models contrasting early and late waves (these models are available from the authors). The results are broadly consistent across time. However, we observe one notable difference: the coefficients for stateness and corporateness are almost uniformly smaller in magnitude in the later waves of the WVS. The institutionalized differences across industrialized societies appear to be eroding over time.

\section{Toward A Multifaceted Understanding of Political Activity}

We have shown that different forms of political behavior, which scholars often separate analytically, fit in a broad ecology that is shaped by national-level cultural patterns embedded in institutional constraints and policies. For example, the traditional weakness of civic associationalism in statist countries coincides with, on the one hand, the greater activity of the fewer members who get involved, and, on the other, a greater engagement of citizens in what may be called "routinized contention." ${ }^{7}$ Voluntary-association participation does not operate independently from contentious politics; rather, the two are intimately linked by embedded institutional constraints and cultural logics of participation. Second, we have argued 
and demonstrated that two dimensions of the cultural organization of polities stateness and corporateness - account for much of the cross-national differences in the configuration of the political sphere.

To the extent that this sphere can be thought of as an ecology, there is a need for holistic and integrated analyses of political activity. This paper represents a step in that direction, focusing mainly on voluntary activity and social movements. However, these forms of political activity obviously intertwine with other phenomena, such as citizens' use of the legal system, their voting behavior, or the formal role of interest groups. Schudson (2000), for example, has argued that contentious social action in the United States may be less prominent than in other countries because much contention is effectively channeled through the court system. Likewise, as we have shown elsewhere, corporateness tends to lock in certain forms of interest-representation within the state, curtailing participation in "new" social movements and groups (Schofer and Fourcade-Gourinchas 2001). These complex configurations cannot be apprehended from the vantage point of any one sub-field, but rather require a multifaceted approach to the varying configuration of political activity in different societies.

Another, quite different, area for future work involves the development of better quantitative measures - both of forms of political activity and of polity characteristics such as stateness and corporateness. Measurement of polity characteristics poses a challenge. Simple measures such as "state size" do not effectively measure stateness because some fiscally large states can be quite decentralized and effectively incorporate civil groups in their mode of functioning (e.g., Sweden). Measures of the "elite" character of the civil service hold more promise as a distinct hallmark of statist societies. Efforts to expand the geographical and temporal coverage of such measures would open up many avenues for new empirical research. Finally, there are numerous measures of corporatism, but most focus on labor relations and industrial policy more so than the actual degree of corporateness of a polity. Most useful are measures that tap into the extent to which legal rights or state resources accrue to collectivities (not merely "individual" members of particular social groups).

The literature could also be advanced through further investigation of the meaning of political activity across societies, thereby bringing some of the current concerns of social-movement scholars about the incorporation of identity questions (Polletta and Jasper 2001) into comparative research. This is not a call for further studies of "values," but rather for the exploration of broad shared logics and cultural understandings of the way politics works. It is one thing to show that demonstrations are more common in France than in the United States. But it is more fruitful to understand the extent to which such differences arise from nationally structured logics of participation. The preponderance of a given form of political activity, whether it be "joining" or "striking," is likely to be intertwined with its culturally situated meaning. Such variations also raise a strong cautionary note for sociologists. The celebration of voluntary association in the social-capital literature may in part reflect the seeping of local cultural assumptions into the analytical framework being employed. This can lead to the tendency to view American-style private association as inherently better or more effective than the alternative config- 
urations found elsewhere (e.g., the collective-negotiation arrangements common among corporate societies). In fact, the comparative efficacy of different systems is not well understood or systematically studied. Moreover, strong normative biases serve to obscure the critical sociological issue at hand: understanding the distinctive cultural logics of those systems.

One issue remains: that of change over time. The institutional arrangements and political structures of stateness and corporateness are durable, but not monolithic and inert. There are many sources of endogenous change, generating rich variations in political life (e.g., types of corporatism) within the broad categories we rely upon. However, these are manifold, and largely outside of the theoretical and empirical scope of this paper. There are also exogenous forces at work. Of particular relevance may be the construction of supranational political institutions (such as the European Union) and nations' embeddedness in "world society."

As many have noted, the world society is dominated by a liberal political and economic ideology, which finds its cultural origins in Western rationalism (Meyer, Boli, and Thomas 1987). To participate in this polity generally means adopting a set of legitimated practices and working through accepted vehicles of action, such as international non-governmental organizations (Boli and Thomas 1999), international economic and legal institutions (Boyle 2001), among others. The legitimacy of these liberal forms of economic organization and political activity within world society may be one of the underlying forces that prompt their isomorphic diffusion across national polities. It is quite remarkable, for instance, that in a number of countries the retreat of the state from many areas of economic and social life has been accompanied by policies supporting a substitution by the voluntary sector. This is particularly evident in the case of welfare and health (Gaskin and Smith 1997).

This transnational reconstruction of the political is obviously more explicit and potent in the case of the European Union. According to social movement scholarship, the increasing centralization of responsibilities in Brussels should stimulate collective action at the European level. However, this migration of the locus of action from the national to the transnational level should be limited because no European "state" exists yet (Tarrow 1994). Nevertheless, as Europe consolidates itself, patterns of civic involvement and political activity will depend critically not only on the scope and structure of European political opportunities or the policies institutionalized in various sectors, but also on the representations of political sovereignty embedded in European institutions.

Although it is important to think about change, our story is much more about the past than the future. It is about the institutional and cultural ways in which historically evolved social and political structures shape the very possibility and forms of political action. Certainly, our approach is quite crude, mainly identifying and accounting for stable cross-national differences in broadly defined forms of mobilization. A deeper analysis, which we have suggested at various points in this text, would go further into exploring how the same form (e.g., a street demonstration) still bears a different meaning for those who partake in it in different countries (but see Fourcade, Lande, and Schofer 2016). Yet we believe that the framework we have 
laid out still captures something important about the relationship between social and political structures and political mobilization.

Finally, our findings intersect in interesting ways with those of Albert Hirschman (1970), who analyzed the conditions under which people will "exit" an institution they disapprove of, "voice" their hostility or remain "loyal." As it turns out, his argument revolves in part around the role of social structures. Throughout their history, he argues, Americans have always privileged "exit" solutions: born into the "exit" of emigration, American national culture has evolved in a constant reenactment of its origins - most obvious in the frontier movement, and in the ever renewed myth of "starting over" through residential mobility and personal reinvention (Jasper 2000). The main reason is that defection is easier the more open a society is, the less "family, primary groups and various kinds of membership groups" play a crucial role, the less differentiated the state, and the greater the role of the market (Birnbaum 1988:20; also see Hirschman 1982).

Certainly all the political forms analyzed in this paper would fall under Hirschman's "voice" category. Yet if we look closer we come to realize that some are really hybrids: boycotts, and perhaps strikes too, are more "private" or "market-oriented," corresponding to the lesser differentiation between politics and economics in liberal societies, while demonstrations and building occupations are more visibly "public" and narrowly political, corresponding to the inescapable orientation toward the state. Perhaps, then, we should revive the public/private distinction as a useful way to re-conceptualize the multifaceted nature of the political - not by pinning the public-political against the private-economic, as is often done, but by acknowledging that the distinction runs through the political category itself.

\section{Notes}

1 See Anton 1980; Rothstein 2002:291; Trägårdh 2007.

2 See Birnbaum (1988:107-116) for a review.

3 Lamartine, Oeuvres, Pagnerre, Tome XIII, p.182. Cited in Jaume (1997). (translation: Marion Fourcade)

4 See also Chirot's (1980:367) description of the Eastern and Southern European fascisms in the 1930s: "As in Italy, the fascists sold out their corporatist dreams to cement a cynical alliance with established elites. They gained power but lost their corporatism."

5 Here we refer to the fact that a high proportion of political leaders and private industry leaders in both countries have been civil servants. See, e.g., Birnbaum and Badie (1983) on France, and Hamilton and Biggart (1988) on Japan.

6 See Black (1996) on the historical connection between stateness and the Catholic Church.

7 Note, however, that this is not a story of functional equivalence. We are not suggesting that all societies, despite variation in forms, somehow generate equivalent capacity for political action, citizen engagement, and the provision of various collective goods. In the United States, for instance, citizens and civil-society groups really do shape local politics (e.g., educational policy) to a greater extent than can be found in most statist societies. Corporate concertation arrangements generate effective industry-labor coordination types uncommon in non-corporate societies. Systematic comparative studies of these sorts of differences would be a useful direction for future research. 


\section{References}

Almond, Gabriel A. 1960. "A Functional Approach to Comparative Politics." Pp. 3-64 in The Politics of the Developing Areas, edited by Gabriel A. Almond and James S. Coleman. Princeton: Princeton University Press.

Almond, Gabriel A. and Sidney Verba. 1963. The Civic Culture. Princeton, NJ: Princeton University Press.

Aminzade, Ron and Doug McAdam. 2001. "Emotions and Contentious Politics." Pp. 14-50 in Silence and Voice in the Study of Contentious Politics, edited by Ron Aminzade. Cambridge [England]: Cambridge University Press. http://dx.doi.org/10.1017/ CB09780511815331.003

Anheier, Helmut. 1991. “West Germany: The Ambiguities of Peak Associations.” Pp. 64-93 in Between States and Markets: The Voluntary Sector in Comparative Perspective, edited by Robert Wuthnow. Princeton, NJ: Princeton University Press.

Anton, Thomas J. 1980. Administered Politics. Elite Political Culture in Sweden. Boston: Martinus Nijhof Publishing.

Bail, Christopher. 2008. "The Configuration of Symbolic Boundaries against Immigrants in Europe", American Sociological Review, 73(1): 37-59. http://dx.doi.org/10.1177/ 000312240807300103

Beckert, Jens. 2007. Inherited Wealth. Princeton: Princeton University Press.

Berger, Peter and Thomas Luckmann. 1966. The Social Construction of Reality. New York, NY: Anchor Books, Doubleday.

Berman, Sheri. 1997a. "Civil society and Political Institutionalization." The American Behavioral Scientist. 40(5):562-675. http://dx.doi.org/10.1177/0002764297040005003

Berman, Sheri. 1997b. "Civil Society and the Collapse of the Weimar Republic." World Politics 49(3):401-429. http://dx.doi.org/10.1353/wp.1997.0008

Birnbaum, Pierre. 1988. States and Collective Action. Cambridge [England]: Cambridge University Press. http://dx.doi.org/10.1017/CB09780511598630

Birnbaum, Pierre and Bertrand Badie. 1983. The Sociology of the State. Chicago, IL: University of Chicago Press.

Black, Anthony. 1996. "Individuals, Groups and States: A Comparative Overview." Pp. 328-340 in The Individual in Political Theory and Practice, edited by Janet Coleman. Oxford [England]: Clarendon Press.

Boli, John. 1991. “Sweden: Is there a Viable Third Sector?" Pp. 94-124 in Between State and Market: The Voluntary Sector in Comparative Perspective, edited by Robert Wuthnow. Princeton, N.J.: Princeton University Press.

Bonikowski, Bart. 2010. "Cross-National Interaction and Cultural Similarity: A Relational Analysis." International Journal of Comparative Sociology 51:315-48. http://dx. doi .org/ 10.1177/0020715210376854

Bonnell, Victoria, and Lynn Hunt, eds. 1999.Beyond the Cultural Turn. New Directions in the Study of Society and Culture(Vol. 34). Berkeley, CA: University of California Press.

Bourdieu, Pierre. 2015. On the State. Cambridge: Polity.

Boyle, Elizabeth H. 2001. "National Politics and Resort to the European Commission on Human Rights." Law and Society Review, 35(2):321-44. http://dx.doi .org/10.2307/ 3185405 
Brady, Henry, Sidney Verba and Kay Lehman Schlozman. 1995. “Beyond SES: A Resource Model of Political Participation." American Political Science Review 89(2):271-194. http: //dx.doi.org/10.2307/2082425

Bryk, Anthony S. and Stephen Raudenbush. 1992. Hierarchical Linear Models: Applications and Data Analysis Methods. Newbury Park, CA: Sage.

Carter, Bob, Peter Fairbrother, Rachel Sherman and Kim Voss. 2003. "Made in the USA, Imported into Britain: The Organizing Model and the Limits of Transferability." Pp. 59-78 in Research in the Sociology of Work. Vol. 11: Labor Revitalization: Global Perspectives and New Initiatives, edited by Dan Cornfield and Holly McCammon. Kidlington, Oxford, U.K.: JAI Press. http: //dx.doi.org/10.1016/s0277-2833(03)11003-5

Chirot, Daniel. 1980. “The Corporatist Model and Socialism." Theory and Society. 9(2): 363-381. http://dx.doi.org/10.1007/bf00207282

Clemens, Elisabeth and Debra Minkoff. 2004. "Beyond the Iron Law: Rethinking the Place of Organizations in Social Movement Research. Pp. 155-216 in The Blackwell Companion to Social Movements, edited by David Snow, Sarah A. Soule and Hanspeter Kriesi. London: Blackwell. http://dx.doi.org/10.1002/9780470999103.ch7

Crozier, Michel. 1973. The Stalled Society. New York, NY: Viking Press.

Curtis, James E, Douglas E. Baer, and Edward G. Grabb. 2001. "Nations of Joiners: Explaining Voluntary Association Membership in Democratic Societies." American Sociological Review, 66:783-805. http://dx.doi.org/10.2307/3088873

Curtis, James, Edward Grab and Douglas Baer. 1992. "Voluntary Association Membership in Fifteen Countries: A Comparative Analysis." American Sociological Review, 57:139-52. http://dx.doi.org/10.2307/2096201

Dyson, Kenneth. 1980. The State Tradition in Western Europe. Oxford [England]: Martin Robertson.

Eliasoph, Nina. 1998. Avoiding Politics. How Americans Produce Apathy in Everyday Life. Cambridge University Press. http://dx.doi .org/10.1017/CB09780511583391

Esping-Andersen, Gøsta. 1990. The Three Worlds of Welfare Capitalism. Princeton, N.J.: Princeton University Press.

Esping-Andersen, Gøsta. 1999. Social Foundations of Postindustrial Economies. Oxford/New York: Oxford University Press. http://dx.doi.org/10.1093/0198742002.001.0001

Evans, Peter and James Rauch. 1999. "Bureaucracy and Growth: A Cross-National Analysis of the Effects of 'Weberian' State Structures on Economic Growth." American Sociological Review. 64(5). http://dx.doi.org/10.2307/2657374

Favre, Pierre. 1990. La Manifestation. Paris: Presses de la Fondation Nationale des Sciences Politiques.

Fourcade, Marion, Brian Lande, and Evan Schofer. 2016. "Political Space and the Space of Polities: Doing Politics Across Nations." Poetics. 55:1-18.

Friedland, Roger and Robert R. Alford. 1991. “Bringing Society Back In: Symbols, Practices and Institutional Contradictions." Pp. 232-263 in The New Institutionalism in Organizational Analysis, edited by Walter Powell and Paul DiMaggio. Chicago, Ill.: University of Chicago Press.

Ganz, Marshall. 2008. Why David Sometimes Wins: Leadership, Organization and Strategy in the California Farm Worker Movement. Oxford University Press, 2009.

Gaskin, Katharine and Justin Davis Smith. 1997. A New Civic Europe? A Study of the Extent and Role of Volunteering. London [England]: The National Centre for Volunteering. 
Hamilton, Garry and Nicole Biggart. 1988. "Market, Culture, and Authority: a Comparative Analysis of Management and Organization in the Far East." American Journal of Sociology. 94: 52-94. http://dx.doi.org/10.1086/228942

Hall, Peter A. 2002. "Social Capital in Britain." Pp. 21-58 in Democracies in Flux. The Evolution of Social Capital in Contemporary Society, edited by Robert Putnam. Oxford University Press. http://dx.doi.org/10.1093/0195150899.003.0002

Hattam, Victoria. 1992. "Institutions and Political Change. Working-Class Formation in England and the United States. 1820-1896." Politics and Society 20(2):133-66. http: //dx.doi.org/10.1177/0032329292020002002

Hirschman, Albert O. 1970. Exit, Voice and Loyalty. Responses to Decline in Firms, Organizations and States. Cambridge, MA: Harvard University Press.

Hirschman, Albert. 1994. "Social Conflicts as Pillars of Democratic Market Society." Political Theory 22(2):203-218. http://dx.doi.org/10.1177/0090591794022002001

Hirschman, Albert O. 2002 (1982). Shifting Involvements. Private Interests and Public Action. Princeton, NJ: Princeton University Press.

IDEA 2009. IDEA Voter Turnout Database. International Institute for Democracy and Electoral Assistance.

Inglehart, Ronald. 1997. Modernization and Post-Modernization: Cultural, Economic and Political Change in 43 Societies. Princeton, NJ: Princeton University Press.

Jasper, James. 2000. Restless Nation. Starting Over in America. Chicago, Ill.: University of Chicago Press. http://dx.doi.org/10.7208/chicago/9780226394732.001.0001

Jasper, James. 2011. “Emotions and Social Movements: Twenty Years of Theory and Research." Annual Review of Sociology 37:285-303. http: //dx . doi . org/10.1146/annurevsoc-081309-150015

Jaume, Lucien. 1997. L'Individu effacé, ou le paradoxe du libéralisme français. Paris: Fayard.

Jepperson, Ronald. 1991. “Institutions, Institutional Effects, Institutionalism.” Pp. 143-163 in The New Institutionalism in Organizational Analysis, edited by Walter Powell and Paul DiMaggio. Chicago, Ill.: University of Chicago Press.

Jepperson, Ronald. 1993. National Scripts: The Varying Construction of Individualism and Opinion across the Modern Nation-States, Unpublished PhD Dissertation, Yale University.

Jepperson, Ronald. 2002. "Political Modernities: Disentangling Two Underlying Dimensions of Institutional Differentiation." Sociological Theory. 20(1):61-85. http://dx.doi .org/10 . 1111/1467-9558.00151

Jepperson, Ronald and John Meyer. 1991. "The Public Order and the Construction of Formal Organizations." Pp. 204-231 in The New Institutionalism in Organizational Analysis edited by Walter Powell and Paul DiMaggio. Chicago: University of Chicago Press.

Katznelson, Ira. 1985. “Working Class Formation and the State: Nineteenth Century England in American Perspective." Pp. 257-284 in P. Evans, D. Rueschmeyer and T. Skocpol (eds.) Bringing the State Back In, edited by P. Evans, D. Rueschmeyer and T. Skocpol. Cambridge University Press. http://dx.doi.org/10.1017/CB09780511628283.012

Kaufman, Jason. 2002. For the Common Good? American Civic Life and the Golden Age of Fraternity. Oxford University Press.

Kitschelt, Herbert. 1986. Political Opportunity Structures and Political Protest: Anti-Nuclear Movements in Four Democracies. British Journal of Political Science 16:57-85. http://dx . doi.org/10.1017/S000712340000380X

Kriesi, Hanspeter. 1996. “The Organizational Structure of New Social Movements in a Political Context." Pp. 152-184 in Comparative Perspectives on Social Movements. Political 
Opportunities, Mobilizing Structures and Cultural Framings, edited by Douglas McAdam, John McCarthy and Mayer Zald. Cambridge [England]: Cambridge University Press. http://dx.doi.org/10.1017/CB09780511803987.009

Kriesi, Hanspeter, Jan Willem Duyvendak, Marco G. Giugni, and Ruud Koopmans. 1995. The Politics of New Social Movements in Western Europe. Minneapolis and St. Paul: University of Minnesota Press.

La Porta, Rafael, Florencio Lopez-de-Silanes, Andrei Schleifer, and Robert W. Vishny. 1998. "Law and Finance." Journal of Political Economy, 106, 6:1113:1155. http://dx. doi .org/10. $1086 / 250042$

Lijphart, Arend. 1999. Patterns Of Democracy: Government Forms and Performance in Thirty-Six Countries. New Haven: Yale University Press.

Mann, Michael. 1986. "The Autonomous Power of the State: Its Origins, Mechanisms, and Results." Pp. 109-136 in John A. Hall, ed., States in History, edited by John A. Hall, ed. Oxford University Press.

Marshall, Monty G. and Keith Jaggers. 2007. Polity IV Project: Dataset User's Manual. Fairfax, VA; Center for Global Policy, George Mason University.

McAdam, Douglas, John McCarthy and Mayer Zald (eds.) 1996. Comparative Perspectives on Social Movements. Political Opportunities, Mobilizing Structures and Cultural Framings. Cambridge [England]: Cambridge University Press. http://dx .doi .org/10.1017/ CB09780511803987

McAdam, Douglas and Sidney Tarrow. 2010. "Ballots and Barricades: On the Reciprocal Relations between Elections and Social Movements." Journal of Politics 8(2): 529-542. http://dx.doi.org/10.1017/s1537592710001234

McAdam, Douglas, Sidney Tarrow and Charles Tilly. 2001. Dynamics of Contention. Cambridge and New York: Cambridge University Press. http://dx.doi.org/10.1017/ CB09780511805431

Meyer, John W., John Boli, and Georges Thomas. 1987. “Ontology and Rationalization in Western Cultural Account." Pp. 12-37 in Institutional Structure: Constituting State, Society, and Individual, edited by George M. Thomas, John W. Meyer, and Francisco O. Ramirez. Newbury Park, CA: Sage.

Mitchell, Timothy. 1991. "The Limits of the State: Beyond Statist Approaches and Their Critics." The American Political Science Review. 85(1):77-96. http://dx . doi .org/10.1017/ s0003055400271451

Nettl, John P. 1968. “The State as a Conceptual Variable." World Politics 20(4): 559-592. http://dx.doi.org/10.2307/2009684

Nollert, Michael. 1995. "Neocorporatism and Political Protest in Western Democracies: A Cross-National Analysis." Pp. 138-164 in The Politics of Social Protest. Comparative Perspectives on States and Social Movements, edited by J. Craig Jenkins and Bert Klandermans. Minneapolis, MN: The University of Minnesota Press.

Novak, William. 2008. "The Myth of the Weak American State." American Historical Review 113(3): 752-772. http://dx.doi.org/10.1086/ahr.113.3.752

O'Donnell, Guillermo. 1977. “Corporatism and the Question of the State." Pp. 47-87 in Authoritarianism and Corporatism in Latin America, edited by James Malloy. University of Pittsburgh Press.

Offe, Claus. 1983. “The Attribution of Public Status to Interest Groups: Observations on the German Case." Pp. 123-158 in Organizing Interests in Western Europe. Pluralism, 
Corporatism, and the Transformation of Politics, edited by Suzanne Berger. Cambridge [England] and New York, NY: Cambridge University Press.

Panitch, Leo. 1980. "Recent Theorizations of Corporatism." British Journal of Sociology. June.

Polletta, Francesca and James Jasper. 2001. "Collective Identity and Social Movements." Annual Review of Sociology. 27:283-305. http://dx. doi .org/10.1146/annurev . soc . 27. 1.283

Portes, Alejandro and Patricia Landolt. 1996. "The Downside of Social Capital." The American Prospect, 26, May-June:18-21.

Putnam, Robert. 2000. Bowling Alone: The Collapse and Revival of American Community. New York: Simon and Schuster. http://dx.doi.org/10.1145/358916.361990

Putnam, Robert (ed.) 2002. Democracies in Flux. The Evolution of Social Capital in Contemporary Society. Oxford University Press. http://dx.doi.org/10.1093/0195150899.001.0001

Putnam, Robert D., with Robert Leonardi, and Raffaella Y. Nanetti. 1992. Making Democracy Work: Civic Traditions in Modern Italy. Princeton, NJ: Princeton University Press.

Riley, Dylan John. 2010. The Civic Foundations of Fascism in Europe: Italy, Spain, Romania 1870-1945. The Johns Hopkins University Press.

Rothstein, Bo. 2002. "Sweden: Social Capital in the Democratic State." Pp. 289-331 in R. Putnam (ed.) Democracies in Flux. The Evolution of Social Capital in Contemporary Society, edited by R. Putnam. Oxford University Press. http://dx.doi.org/10.1093/ 0195150899.003 .0008

Schmitter, Philippe C. 1974. "Still the Century of Corporatism?" Review of Politics 36:85-131. http://dx.doi.org/10.1017/S0034670500022178

Schofer, Evan and Marion Fourcade-Gourinchas. 2001. "The Structural Contexts of Civic Engagement. Voluntary Associations Membership in Comparative Perspective." American Sociological Review. 66(6): 806-828. http://dx.doi.org/10.2307/3088874

Schudson, Michael. 2000. The Good Citizen. A History of American Civic Life. Cambridge, MA: Harvard University Press.

Schussman, Alan and Sarah Soule. 2005. "Process and Protest: Accounting for Individual Protest Participation." Social Forces 84(2): 1083-1104. http://dx.doi.org/10.1353/sof . 2006.0034

Sewell, William H. Jr. 1999. "The Concept(s) of Culture." In Beyond the Cultural Turn. New Directions in the Study of Society and Culture (Vol. 34), edited by Victoria Bonnell and Lynn Hunt. Berkeley, CA: University of California Press.

Sewell, William H. Jr. 1980. Work and Revolution in France. The Language of Labor from the Old Regime to 1848. Cambridge [England] \& New York, NY: Cambridge University Press. http://dx.doi.org/10.1017/CB09780511583711

Shorter, Edward and Charles Tilly. 1974. Strikes in France 1830-1968. London and New York: Cambridge University Press.

Silberman, Bernard. 1993. Cages of Reason. The Rise of the Rational State in France, Japan, the United States and Great Britain. Chicago, Ill.: The University of Chicago Press.

Skocpol, Theda. 1995. Protecting Soldiers and Mothers. The Political Origins of Social Policy in the United States. Belknap Press.

Skocpol, Theda. 2003. Diminished Democracy: From Membership to Management in American Civic Life. University of Oklahoma Press.

Skocpol, Theda, Marshall Ganz and Ziad Munson. 2000. “A Nation of Organizers: The Institutional Origins of Civic Volunteerism in the United States." American Political Science Review 94(3): 527-546. http://dx.doi .org/10.2307/2585829 
Somers, Margaret. 1995. "Narrating and Naturalizing Civil Society and Citizenship Theory: The Place of Political Culture and the Public Sphere." Sociological Theory 13(3):229-274. http://dx.doi.org/10.2307/223298

Steinmetz, George. 1999. "Introduction: Culture and the State." Pp. 1-49 in G. Steinmetz (ed.) State/Culture: State Formation After the Cultural Turn, edited by George Steinmetz. Ithaca, N.Y.: Cornell University Press. http://dx.doi .org/10.1300/j002v28n03_01

Streeck, Wolfgang and Philip Schmitter. 1985. "Community, Market, State — and Associations? The Prospective Contribution of Interest Governance to Social Order." European Sociological Review 1(2):119-138.

Swidler, Ann. 1986. "Culture in Action: Symbols and Strategies". American Sociological Review 51:273-286. http://dx.doi.org/10.2307/2095521

Swidler, Ann. 2001. "What Anchors Cultural Practices". Pp. 74-92 in The Practice Turn in Contemporary Theory, edited by Karin Knorr-Cetina, Eike von Savigny, and Theodore R. Schatzki. Routledge.

Tarrow, Sidney. 1988. "National Politics and Collective Action: Recent Theory and Research in Western Europe and the United States." Annual Review of Sociology. 14:421-440. http: //dx.doi.org/10.1146/annurev.so.14.080188.002225

Tarrow, Sidney. 1989. Democracy and Disorder. Protests and Politics in Italy 1965-1975. Clarendon Press.

Tarrow, Sidney. 1994. Power in Movement: Social Movements, Collective Action, and Politics. Cambridge University Press.

Thomas, George M, John W. Meyer, and Francisco O. Ramirez, eds. 1987. Institutional Structure: Constituting State, Society, and Individual. Newbury Park, CA: Sage.

Tocqueville, Alexis de. 1955 (1856). The Old Regime and the French Revolution. New York, N.Y.: Doubleday.

Tocqueville, Alexis de. 2000 (1835 and 1840). Democracy in America. Chicago, Ill.: University of Chicago Press. http://dx.doi.org/10.7208/chicago/9780226924564.001.0001

Tilly, Charles. 1986. The Contentious French. Cambridge, Mass.: Belknap Press. http: //dx.doi.org/10.4159/harvard.9780674433984

Tilly, Charles. 2003. Contention and Democracy in Europe. 1650-2000. Cambridge [England]: Cambridge University Press. http://dx . doi.org/10.1017/CB09780511756092

Tilly, Charles. 2008. Contentious Performances. Cambridge [England]: Cambridge University Press. http://dx.doi.org/10.1017/CB09780511804366

Trägårdh, Lars (ed.). 2007. State and civil Society in Northern Europe. The Swedish Model Reconsidered. New York: Berghahn Books.

Vaisey, Stephen. 2009. Motivation and Justification: A Dual-Process Model of Culture in Action. American Journal of Sociology 114(6): 1675-1715. http://dx.doi .org/10.1086/ 597179

Verba, Sidney, Kay L. Scholzman and Henry Brady. 1995. Voice and Equality. Civic Voluntarism in American Politics. Harvard University Press.

Voss, Kim. 1996. "The Collapse of a Social Movement: The Interplay of Mobilizing Structures, Framing and Political Opportunities in the Knights of Labor." Pp. 227-260 in Comparative Perspectives on Social Movements: Political Opportunities, Mobilizing Structures and Cultural Framings, edited by Douglas McAdam, John D. McCarthy, and Mayer N. Zald. Cambridge [England]: Cambridge University Press. http://dx.doi .org/10. $1017 /$ CB09780511803987.012 
Walder, Andrew G. 2009. "Political Sociology and Social Movements." Annual Review of Sociology 35: 393-412. http: //dx. doi .org/10.1146/annurev-soc-070308-120035

Western, Bruce. 1997. Between Class and Market. Postwar Unionization in the Capitalist Democracies. Princeton: Princeton University Press.

Wiarda, Howard. 1982. "From Corporatism to Neo-Syndicalism: The State, Organized Labor, and the Changing Industrial Relations Systems of Southern Europe." Pp. 3-57 in Comparative Social Research Vol. V, edited by Richard Tomasson. Westport, Connecticut: JAI Press.

Wollebaek, Dag and Peter Selle. 2003. “The Importance of Passive Membership for Social Capital Formation." Pp. 68-88 in Generating Social Capital. Civil Society and Institutions in Comparative Perspective, edited by Marc Hooghe and Dietlind Stolle. New York, N.Y.: Palgrave MacMillan.

World Bank. 2010. World Development Indicators 2010. Washington, DC: World Bank.

World Values Survey. 2009. World Values Survey 1981-2008 Official Aggregate v.20090901.

Wuthnow, Robert. 1998. Loose Connections. Joining Together in America's Fragmented Communities. Cambridge, MA: Harvard University Press.

Zhao, Dingxin. 2010. "Theorizing the Role of Culture in Social Movements: Illustrated by Protests and Contentions in Modern China." Social Movement Studies. 9: 33-50.http: //dx.doi.org/10.1080/14742830903442493

Acknowledgements: The authors contributed equally to this article. We thank Irene Bloemraad, Steven Brint, David Frank, Ann Hironaka, Ronald Jepperson, Howard Kimmeldorf, John Meyer, Francisco Ramirez, Sandra Smith, Sarah Soule; members of the Stanford Comparative Workshop and the Irvine Comparative Sociology Workshop. The usual disclaimer applies.

Marion Fourcade: Department of Sociology, University of California, Berkeley. E-mail: fourcade@berkeley.edu.

Evan Schofer: Department of Sociology, University of California, Irvine. E-mail: schofer@uci.edu. 